seen, and for which several steps of mucus releasing are found. The aspect and distribution of the enterocytes and of the mucosal cells change from one intestinal part to the other. In the same part, we can observe different aspects depending on the presence or not of an epithelial fold.

The cell turnover in photonic microscopy is shown by some extrusion areas that we often find with scanning electronic microscope. Furthermore, in an ultrastructural study of the intestine, we observed a very particular type of cell elimination and some of the cellular aspects observed with scanning electronic microscope might correspond to the raised view of this phenomenon.

\title{
ÉTUDE AU MICROSCOPE ÉLECTRONIQUE A BALAYAGE DES MODIFICATIONS DE L'ÉPITHÉLIUM DE L'INTESTIN GRELE DU PORC APRÈs RÉSECTION PROXIMALE OU DISTALE
}

\author{
Michèle DRIN \\ Laboratoire de Biologie-Vertébrés, \\ Université Paris $X I \mathrm{e}, B a ̂ t .441$, \\ 91400 Orsay
}

Nous avons effectué, parallèlement à l'étude des modifications histologiques de l'intestin grêle, l'observation au microscope électronique à balayage de la muqueuse intestinale après résection de $4 \mathrm{~m}$ de jéjunum proximal ou de jéjuno-iléon.

Chez les opérés au site proximal (Réséqués hauts), à faible grossissement, les villosités duodénales et jéjunales apparaissent moins compactes que chez les témoins, alors que l'aspect des villosités iléales est tout à fait comparable.

Chez les opérés au site distal (Réséqués bas) les villosités duodénales et jéjunales sont plus compactes que chez les témoins alors que les villosités iléales sont plus espacées.

La répartition des différents types morphologiques de villosités à chaque niveau intestinal subit des modifications en fonction du site de l'opération.

L'observation au plus fort grossissement permet de constater dans les deux types de résection l'aspect turgescent des cellules absorbantes aux trois niveaux intestinaux. D'autre part, la proportion de cellules muqueuses est plus importante à chacun des trois niveaux dans les deux types opératoires que chez les témoins.

Après résection proximale la proportion de cellules muqueuses s'accroît principalement au niveau duodénal (l'augmentation étant moins importante aux deux autres niveaux), alors qu'après résection distale l'accroissement est beaucoup plus sensible aux niveaux jéjunal et iléal qu'au niveau duodénal.

\section{SUMMARY}

\section{STUDY BY SCANNING ELECTRONIC MICROSCOPE OF THE CHANGES \\ IN THE PIG SMALI, INTESTINE EPITHELIUM AFTER PROXIMAL, OR DISTAL RESECTION}

Parallel to the study of the histological changes in the small intestine, we used the scanning electronic microscope to examine intestinal mucosa after resection of $4 \mathrm{~m}$ of the proximal jejunum or of the jejuno-ileum. 
In the proximal resected animals (upper part resection), with a small magnifying, the duodenal and jejunal villi appeared to be less dense than in the controls, whereas the aspect of the ileal villi was very similar.

In the distal resected animals (lower part resection) duodenal and jejunal villi were more dense than in the controls whereas ileal villi were more spaced.

The distribution of the different morphological types of villi in each intestinal part, undergoes some modifications according to the site of the operation. With a greater magnifying we can observe in both types of resection the turgescent aspect of the absorptive cells in the three intestinal parts. On the other hand, the proportion of mucosal cells is higher in each of the three parts of the intestine after both types of resection than in the controls.

After proximal resection, the mucosal cell proportion mainly increases in the duodenal part (the increase is smaller in the two other parts), whereas after distal resection, the increase is much more pronounced in the jejunal and ileal parts than in the duodenal one. 